\title{
FAULT CURRENT DUE TO ASYNCHRONOUS CONNECTION OF THE GENERATOR TO THE GRID AND IMPACT ON HV CIRCUIT BREAKER WITH GAS SF6
}

\author{
Avni Alidemaj, Sreten Škuletić, Vladan Radulović
}

Original scientific paper

The description and analysis of phenomena that occur in case of disconnection of fault currents with generator circuit breakers after asynchronous connection of a generator and difficulties encountered during the process of disconnection are given in the paper. Generally, the biggest problems occur during the interruption of the fault when the direct current component (DC) is very high. DC component value depends on the type and conditions of the fault. For this purpose, a real study case with accidental asynchronous connection of generator via $400 \mathrm{kV}$ circuit breaker is given from the Kosovo Power System which seriously damages the circuit breaker. For the purposes of this analysis, the real case situation has been also modelled with software such as: EMTP/ATP and PSS/E. It is important to emphasize that during using the high speed AC circuit breaker in power system it is not always the advantage to make successful disconnection of failures through High Voltage Circuit Breaker due to the presence of the high value DC component and the delay of passing of AC current through zero. For the generator the most important is detail analysis of behaviour of the generator in network in order to specify proper circuit breaker that can cover all circumstances that can happen in the system so to be able to protect the generator, step up transformer and other equipment.

Keywords: AC component; asynchronous connection; DC component of fault current; high voltage generator circuit breaker; short circuit

\section{Struja kvara uslijed asinkronog priključka generatora na mrežu i njen utjecaj na visokonaponski prekidač s plinom SF6}

Izvovorni znanstveni članak U radu su dani opis i analiza fenomena koji se događaju u slučaju isključenja struje kvara generatorskim prekidačima nakon asinhronog priključenja generatora i poteškoćama tokom procesa isključenja. Općenito, najveći problemi se javljaju tokom prekida kvara kada je komponenta istosmjerne struje (DC) vrlo visoka. Vrijednost DC komponente ovisi o vrsti i uvjetima kvara. U cilju analize ovog fenomena, u radu je analizirana situacija slučajnog asinhronog priključenja generatora preko $400 \mathrm{kV}$ prekidača u elektroenergetskom sustavu Kosova koja je dovela do oštećenja prekidača. Za potrebe analize, ovaj slučaj je modeliran u softverskim paketima EMTP/ATP i PSS/E. Važno je napomenuti da uporaba brzih AC prekidača u elektroenergetskom sustavu nije uvijek prednost za omogućavanje uspješnog isključenja kvara pomoću visokonaponskog prekidača, zbog prisustva DC komponente s visokim vrijednostima i zakašnjenja prolaza AC struje kroz nulu. Za generatore je najvažnija detaljna analiza ponašanja u mreži kako bi se odredile optimalne karakteristike prekidača u svim okolnostima koje se mogu dogoditi u sustavu, kako bi se omogućila pravilna zaštita generatora, step up transformatora i druge opreme.

Kljućne rijeći: asinkrono priključenje; generatorski prekidač visokog napona; komponenta istosmjerne struje kvara (DC); komponenta izmjenične struje (AC); kratki spoj

\section{Introduction}

During certain faults in the power system there are cases where fault currents delay passing through zero. This occurs when the value of DC current component of the fault current is high and with the long time delay. Furthermore the high values of DC component of current occur also in cases of generator connection to the grid without fulfilling synchronization conditions. The connection of the generator to the grid without meeting synchronization conditions happens very rarely. So, connection without synchronizing condition is accidental and among other things can be a result of failure on control circuits which enable connection of the generator to the grid. Consequences of asynchronous connection of generator to the grid can be different depending on how and in which time has been a closing. Various analyses regarding the phenomenon of appearance of DC component and problems that appear during tripping of the circuit breaker are dealt with in the chapters bellow.

This paper presents analysis of the performance of circuit breaker in disconnection of the failure currents that appear as a result of asynchronous connection of the generator on the grid. The analysis was focused on a real case of presence of DC component of current during asynchronous connection of generator to the network. In addition, the changes of the voltage and current values for further investigation of such problems are recorded.
The work is based on the case of accidental closing of the circuit breaker without synchronization of generator the network, because of failure on the control circuits of generator circuit breaker. This event took place in Kosovo power system. Detailed characteristics will be given in the following chapters. Furthermore the case is modeled using ATP and PSS/E software and results are compared with values recorded in real time of the voltages and currents. The simulation was conducted with ATP and PSS/E software. Furthermore the behavior of the generator during asynchronous connection to the network will be proven from different angles. At the end of the paper the conclusions and recommendations are given, [1].

\section{Asynchronous Connection of Generator-Theoretical Background}

In the power system, synchronization of the generator to network is the process of matching the voltage, frequency and angles of a generator and network. There are three conditions that must be met before the synchronization process takes place, [2].

Synchronous conditions should be attained with the minimization of the following parameters:

- Frequency difference between the two so called "slips" 
- Voltage difference in voltage magnitude between the two sources

- Voltage difference in phase angle between voltages of the two sources

If the synchronization conditions are not met then the damages can happen such as:

- The damages that occur to turbine, generators as results of faulty synchronizing can be either immediate or cumulative (loss of life)

- The excessive slip in frequencies even with zero phase angle and voltage amplitudes, causes power to flow in or out of the generator. The direction of the power flow will be out of the machine if its frequency is greater than the network, or into machine if its frequency is less than the network. The amount of power flow increases as the mismatch increases. This type of oscillation can have consequences in shaft fatigue, bearing failure, fillet and keyway failure, turbine blade root streets, overheating due to high stator currents etc.

- A large voltage difference between sources will cause a flow of reactive power with direction of the flow depending on the relative voltage from the higher to the lower voltage.

Any case when switching on without prior fulfilling of the abovementioned criteria is considered as switching without synchronization. These cases can happen if there is any fault on control circuit, accidental operation etc.

\subsection{Synchronization with Phase Discrepancy of the Generator into the Grid}

In the following are given equations which describe changing of DC and AC (alternative current) components of the current during asynchronous connection of the generator to the network. In this case the AC and DC component of the current changes as per Eqs. (1), (2) and (3):

$$
\begin{aligned}
& i_{\mathrm{dc}}=\frac{2 u_{g}}{x_{d}^{\prime \prime}+x_{T r}+x_{N}} \sin \left(\frac{\theta_{\max }}{2}\right) \cdot \mathrm{e}^{-\frac{t}{T_{\text {atot }}}} \\
& i_{\mathrm{ac}}=\frac{2 u_{g}}{x^{\prime \prime}{ }_{d}+x_{T r}+x_{N}} \sin \left(\frac{\theta}{2}\right) .
\end{aligned}
$$

Where $i_{\mathrm{dc}}$ is the value of the dc component at any instant, and $i_{\mathrm{ac}}$ is the value of the ac component at any instant.

Time constant of DC:

$$
T_{\text {atot }}=\frac{x_{2}+x_{T r}+x_{N}}{\left(r_{a}+r_{T r}+r_{N}\right) 2 \pi f_{n}}
$$

The component of AC current is reduced by change of rotor angle. The circuit breaker has to be able to disconnect all symmetrical and asymmetrical currents associated with presence of high DC current component.

In this context, the very important component of faults current is the DC component. Therefore, it is important to model and determine the DC component of current that needs to be considered in the system so that all types of failures can be covered in order to avoid causing of any damages to breakers, generator and network, as presented in $[2,3,13]$.

\subsection{Impact of Asynchronous Connection of Generator into the Grid.}

During connection of large generators to the network transient electrical and mechanical processes appear. The electromechanical transient processes can cause stress on the generator. If the generator is connected to the network accidentally without respecting synchronization conditions, currents can be very high in range of short circuits. The DC component of current will appear and this can cause high asymmetry of currents between phases. The magnitude of magnetic flux inside generator depends on the position of the rotor's angle against the stator. Since the generator runs with different regimes before failure happens in the moment of failure the flux that occurs does not change immediately. Depending on the type of the failure, the DC component of current can vary.

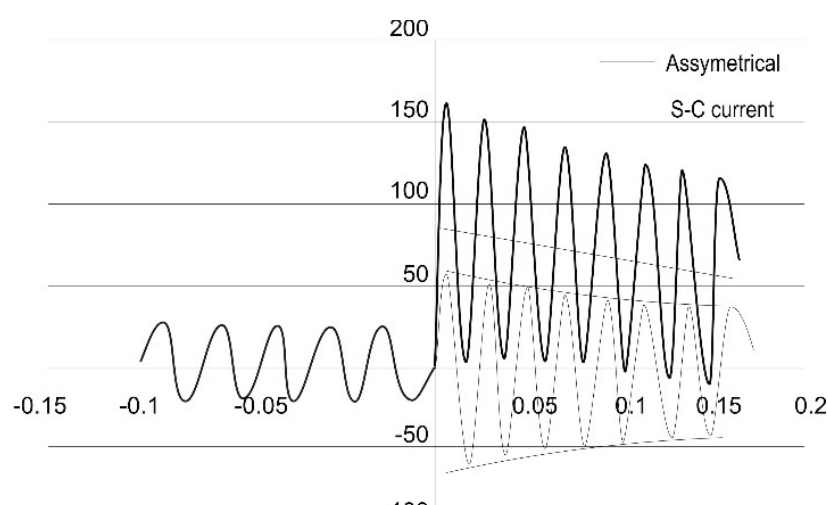

Figure 1 DC component of asymmetrical current on generator-sourced during failure

However, DC component is present also during short circuits. In case of short circuit between the generatorsourced in general the current changes as per the graph provided in Fig. 1 and it is given by Eq. (4). The magnitude of DC component of the failure depends on the type of the failure as well as on the moment when the failure occurs, respectively, on the position of the rotor's angle against the stator $[4,9,10,11]$.

The asymmetric current is expressed with Eq. (4):

$$
\begin{aligned}
& I_{\text {scgen }}=\frac{P \sqrt{2}}{V \sqrt{3}} \cdot\left\{\left[\left(\frac{1}{x_{d}^{\prime \prime}}-\frac{1}{x_{d}^{\prime}}\right) \cdot \mathrm{e}^{-\frac{t}{T_{d}}}+\right.\right. \\
& \left.\left.+\left(\frac{1}{x_{d}^{\prime}}-\frac{1}{x_{d}}\right) \cdot \mathrm{e}^{-\frac{t}{T_{d}}}+\frac{1}{x_{d}}\right] \cdot \cos \omega t-\frac{1}{x^{\prime \prime}{ }_{d}} \cdot \mathrm{e}^{-\frac{t}{T_{d}}}\right\}
\end{aligned}
$$

- $I_{\text {scgen }}$ - short circuit current

- The first term is normal-frequency decaying sub transient current 
- The second term is normal-frequency decaying transient current

- The third term is steady-state short-circuit current

- The forth term is asymmetric decaying dc current.

- $\quad x_{d}^{\prime \prime}, x_{d}^{\prime}, x_{d}$ are direct axis sub transient, transient and synchronous reactance of system.

- $\quad T_{d}^{\prime \prime}, T_{d}^{\prime}, T_{d}$ are sub transient, transient and synchronous Time constants of system

The DC current component is given by Eq. (5):

$$
I_{\mathrm{dc}}=\left(\sqrt{2} \cdot I_{\mathrm{scgen}}\right) \cdot \mathrm{e}^{-\frac{t}{T}}
$$

In Fig. 2 is presented the DC component of current generator-source during short-circuit current for leading or lagging load current (before failure the system is working under inductive/capacitive load) prior to shortcircuit.

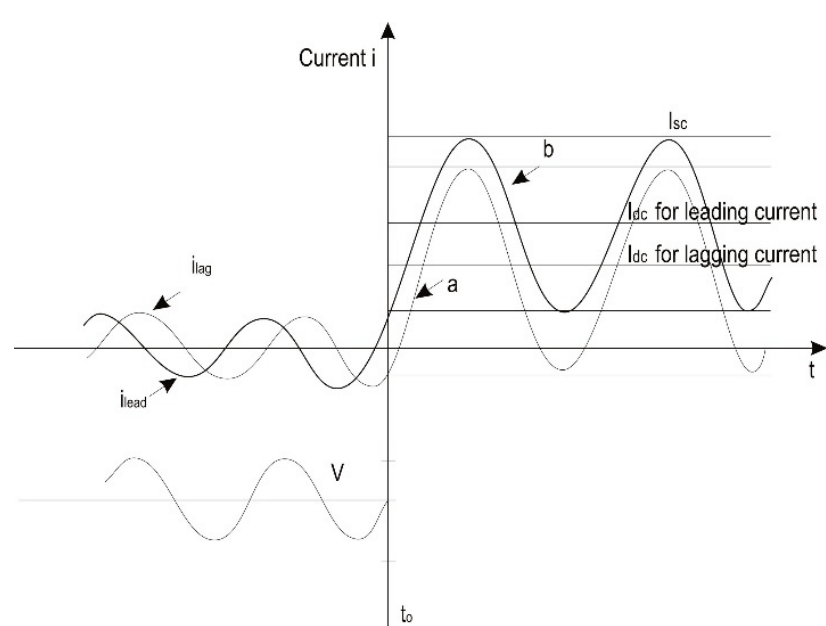

Figure 2 DC component of current in generator during short-circuit for inductive/capacitive load current prior to failure

On the generator side the maximum asymmetric current is reached when the generator is working under excitation before the failure occurs. In these conditions the DC component could be higher than the symmetric short circuit component, hence it influences the delay of the general current short circuit to pass through zero, [3, $14]$.

\subsection{Comparison of required interrupting capability in case of failures}

\subsubsection{Required Generator-source Asymmetrical Interrupting} Capability for Three-phase Faults

For three-phase faults, the required asymmetrical generator-source interrupting capability of a generator circuit breaker at rated maximum voltage and for the rated duty cycle is composed of the rms generator-source symmetrical current and a DC component. The value of the DC component is $110 \%$ of the peak value of the symmetrical generator source short-circuits current for all generator circuit breaker primary arcing contact parting times. The primary arcing contact parting time shall be considered equal to the sum of $1 / 2$ cycle plus the minimum opening time of the particular generator circuit breaker $[4,5,12]$.

\subsubsection{Required Generator-source Asymmetrical Interrupting Capability for Maximum Required Degree of Asymmetry}

Interruption of current from circuit breaker in different circumstances including also a transient condition is presented in the IEC 62271-100, Highvoltage switch gear and control gear-Part 100: Highvoltage alternating-current circuit-breakers, $[4,5,6]$. The rated short-circuit breaking current is characterized by two values:

(1) The rms value of its symmetrical component; the DC time constant of the rated short-circuit breaking current which results in a percentage of DC component at contact separation.

(2) The symmetrical component and the percentage of DC component at any time following current initiation, is presented in Fig. 3, the DC component at contact separation is determined by Eq. (6):

$$
I_{\mathrm{DC}}=I_{\mathrm{AC}} \cdot \mathrm{e}^{\frac{T_{\mathrm{r}}+T_{\mathrm{O}}}{\tau}}
$$

Where: $T_{\mathrm{o}}$ is minimum opening time declared by the manufacturer; $T_{\mathrm{r}}$ is relay time $(0.5$ cycle; $10 \mathrm{~ms}$ for $50 \mathrm{~Hz}$ and $8.3 \mathrm{~ms}$ for $60 \mathrm{~Hz}) ; \tau$-DC is time constant of the rated short-circuit current $(45,60,75$ or $120 \mathrm{~ms})$, IAC-peak value of symmetrical current $[7,8,15]$.

\section{Case Study}

In the year 2011 in substation Kosovo B there was an asynchronous connection of the generator to the grid. The generator was operating normally until the moment the accident occurred. As a result of the faults of the control circuits that control the high voltage $400 \mathrm{kV}$ circuit breaker between the unit - generator- transformer in the network, there was tripping of the circuit breaker. The reconnection was done without respecting synchronization conditions.

The generator is connected to the network by accident under the changing angle of $114^{\circ}$. In these circumstances the maximum value of asymmetric current is $130 \%$ of the peak value of symmetric on this case. In table 1 are given the values recorded during the time of $70 \mathrm{~ms}$. Every 10 $\mathrm{ms}$ the size of the currents is measured, respectively $\mathrm{AC}$ and DC current component.

Table $1 \mathrm{AC}$ and DC component of current depending on time

\begin{tabular}{|c|c|c|c|c|}
\hline \multirow{2}{*}{$T(\mathrm{~ms})$} & \multicolumn{4}{|c|}{ Current } \\
\cline { 2 - 5 } & $I_{\text {rms }}(\mathrm{kA})$ & $I_{\mathrm{DC}}(\mathrm{kA})$ & DC $(\%)$ & $I_{\mathrm{AC}}(\mathrm{kA})$ \\
\hline-20 & 0.44 & 0.15 & 72 & 0.21 \\
\hline-10 & 3.9 & 2.81 & 110.9 & 2.54 \\
\hline 0 & 4.18 & 3.6 & 169 & 2.13 \\
\hline 10 & 3.49 & 3.11 & 198.3 & 1.57 \\
\hline 20 & 3.41 & 3.07 & 205.9 & 1.49 \\
\hline 30 & 2.8 & 2.61 & 260 & 1.0 \\
\hline 40 & 2.76 & 2.6 & 278 & 0.93 \\
\hline 50 & 2.28 & 2.21 & 406 & 0.54 \\
\hline
\end{tabular}

The symmetrical component of the short-circuit current under the condition of maximum degree of asymmetry is only $74 \%$ of the value of the required 
generator-source symmetrical interrupting capability based on recorded measurement which is presented in Tab. 1.

The variation of value of the DC component depends on the time constant of the circuit $T_{a}=X^{\prime \prime}{ }_{d} / R_{a}$, as presented in Fig. 3 [9].

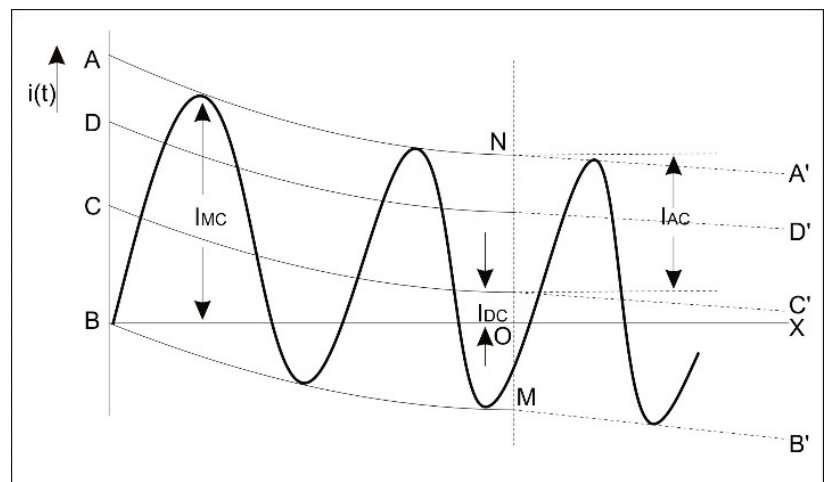

Figure 3 IEC 62271-100, Determination of short-circuit making and breaking currents, and of percentage DC component

\subsection{Overview of Power System of Kosovo}

Power System of Kosovo is a small power system, strongly interconnected with other part of the South East Network of Europe. Geographic position and configuration of the network makes the Kosovo Network very important for the Power System in the region. The main units of generation are connected to the same node (Fig. 4). Because of the size and stability, electrical generators are mainly connected to the substation (SS)
Kosovo B at $400 \mathrm{kV}$ level. High voltage circuit breakers that are in general use in the Kosovo Power System at HV level are circuit breakers with gas SF6. Before the fault happened, the generator operated with the load around $270 \mathrm{MW}$. The fault happened in the generator circuit breaker (CB1 in Fig. 4) on HV voltage side. The wave of current and voltages was recorded by electronic intelligent devices (IED) type Siemens 7SA621 and $7 \mathrm{SJ} 612$ located in the SS $400 / 220 \mathrm{kV}$ on generator bay of TPP Kosovo B, as presented by the single line diagram in Fig. 4, [16].

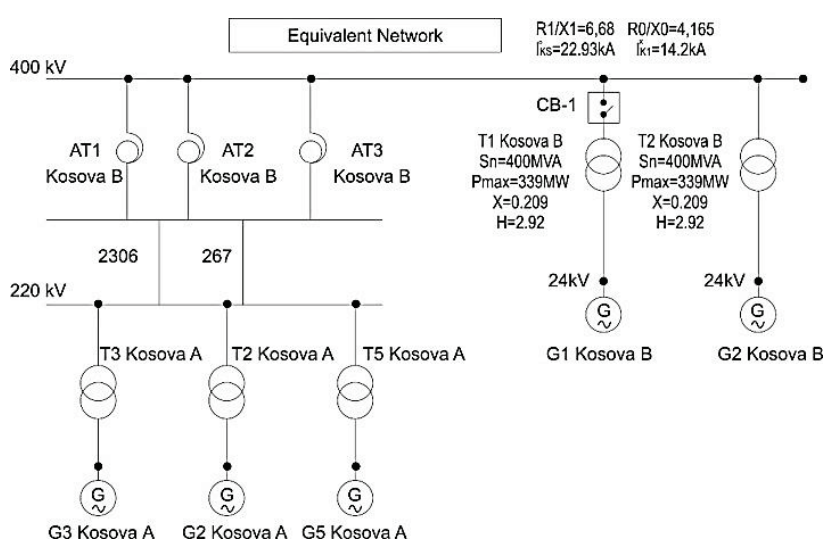

Figure 4 The simplified scheme of connection of the main generators in Power system of Kosovo

Following are the tables with parameters lines and generators in the TPP Kosovo A and B.

Table 2 Dynamic parameters of Turbo generators 399 MVA, 24 kV in Power station Kosovo B

\begin{tabular}{|c|c|c|c|c|c|c|c|c|c|}
\hline$S_{\text {baze }}$ & $\mathrm{Zg}(\mathrm{p} . \mathrm{u})$ & T'D0 & T"D0 & $\mathrm{T}^{\prime} \mathrm{Q} 0$ & T"Q0 & $\mathrm{H}$ & $\mathrm{Bm}$ & XD & $\mathrm{XQ}$ \\
\hline 400 & $0.005+\mathrm{j} 0.209$ & 6.5 & 0.041 & 0.27 & 0.032 & 2.92 & 1 & 2.214 & 2.093 \\
\hline $\mathrm{X}^{\prime} \mathrm{D}$ & $X^{\prime} Q$ & X'’D & $\mathrm{XL}$ & $\mathrm{S}(1.0)$ & $\mathrm{S}(1.2)$ & & & & \\
\hline 0.356 & 0.54 & 0.209 & 0.13 & 0.03 & 0.4 & & & & \\
\hline
\end{tabular}

Table 3 Dynamic parameters of TPP Kosova A3, A4 and A5 generators

\begin{tabular}{|c|c|c|c|c|c|c|c|c|c|}
\hline $\mathrm{S}_{\text {baze }}$ & $\mathrm{Zg}(\mathrm{p} . \mathrm{u})$ & T'D0 & T"D0 & T'Q0 & T"Q0 & $\mathrm{H}$ & $\mathrm{Bm}$ & $\mathrm{XD}$ & $\mathrm{XQ}$ \\
\hline 240 & $0.005+\mathrm{j} 0.188$ & 6.8 & 0.15 & 0.032 & 0.032 & 2.98 & 1 & 1.93 & 1.62 \\
\hline X'D & $X^{\prime} Q$ & X'’D & $\mathrm{XL}$ & $\mathrm{S}(1.0)$ & $\mathrm{S}(1.2)$ & & & & \\
\hline 0.31 & 0.47 & 0.188 & 0.15 & 0.03 & 0.4 & & & & \\
\hline
\end{tabular}

Table 4 Parameter of Overhead Power Lines (OHL) $220 \mathrm{kV}$

\begin{tabular}{|c|c|c|}
\hline Line Number & $\mathrm{Zd}(\mathrm{Rd}+\mathrm{Xd}) \Omega$ & $\mathrm{Zo}(\mathrm{Ro}+\mathrm{Xo}) \Omega$ \\
\hline Line $2306-220 \mathrm{kV}$ & $0.22+\mathrm{j} 1.527$ & $1.02+\mathrm{j} 3.08$ \\
\hline Line $267-220 \mathrm{kV}$ & $0.208+\mathrm{j} 1.443$ & $0.964+\mathrm{j} 2.910$ \\
\hline
\end{tabular}

\subsection{Critical Event}

Before closing the generator to the network any event or any fault were recorded on the system. The failure was due to fault on control circuits used for switching control of high voltage generator circuit breaker. Due to control cable damage, the generator tripped respectively $\mathrm{HV}$ circuit breaker of generator switched off and switched on immediately respectively connected the generator to network without respecting the synchronization conditions and tripped again from protection device. The time between two sequences of open - close of circuit breaker was around $170 \mathrm{~ms}$. Final process opening contact of circuit breaker is presented in Fig. 6. As a consequence, due to this asynchronous connection and the wide voltage angles between the generator and the power system, extremely high transient currents comparable to fault currents during short circuits.

From the oscilographic recording in Fig. 5 it can be concluded that currents on phases L1, L2 and L3 are asymmetric. Asymmetry is caused due to the presence of DC component in each phase. In phase L1, in figure 5 surrounded by square, DC component is very high and as a consequence it causes displacement of $\mathrm{AC}$ component of the current above the axis and delay the current of phase L1 passing through zero for approximately $100 \mathrm{~ms}$.

Disconnection of the current in this case with high speed circuit breaker, is difficult because current does not pass through zero for $100 \mathrm{~ms}$. High speed circuit breaker has capability to interrupt the current for less than $50 \mathrm{~ms}$, but the fault current must pass through the zero. If the current does not pass through zero during the time less than $50 \mathrm{~ms}$, then trying to interrupt this current will be 
difficult or the breaker will be damaged. In our case, the circuit breaker with time constant of $45 \mathrm{~ms}$ was damaged.
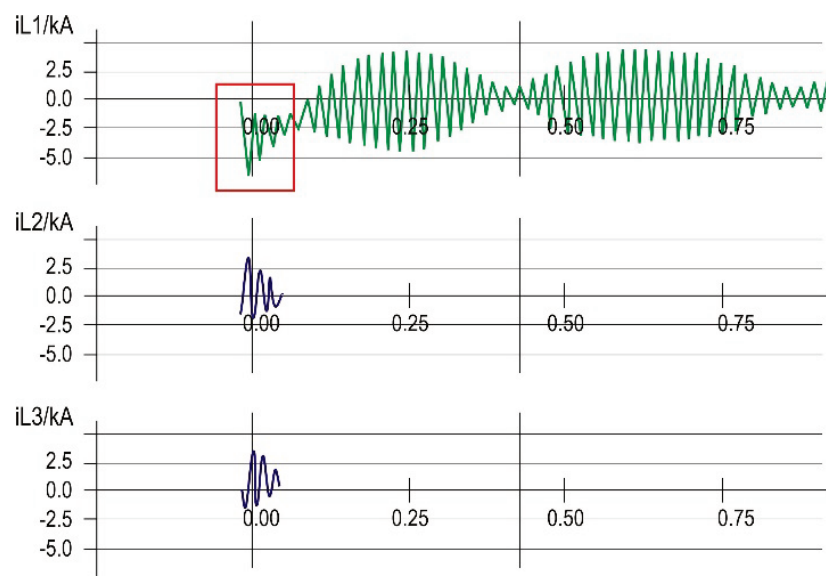

Figure 5 Oscilogram of currents on high voltage 400kVof generator step-up transformer during close-open of Circuit breaker

Fig. 6 shows the damaged main contact in one chamber of the $400 \mathrm{kV}$ generator circuit breaker, [16, 17]. The insulation of one pole of the circuit breaker is destroyed as consequences of the arc flashing appears at every 400 to $600 \mathrm{~ms}$.

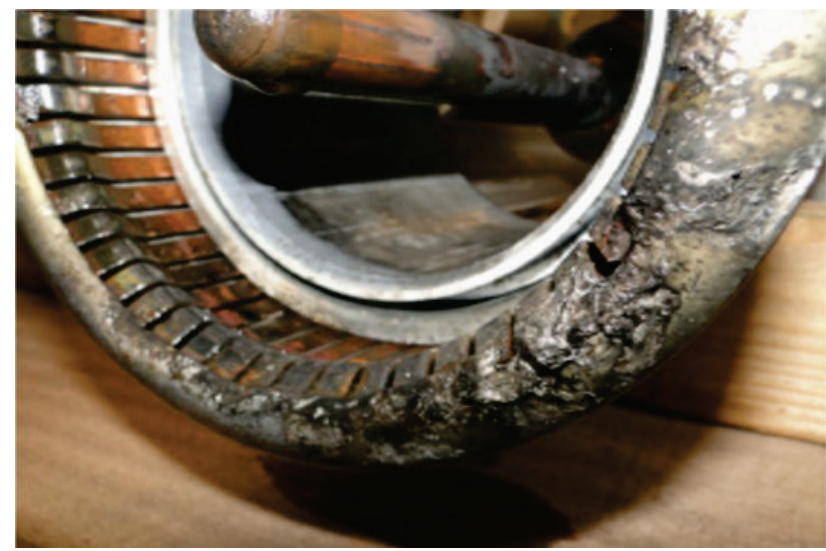

Figure 6 Circuit breaker contacts showing damage caused by electric arc

\section{Simulation Results}

In this part of the study we have developed the model of the part of the system described in case study. The data of the model were used from the characteristics of equipment and case observed.

\subsection{Model Description}

The model of the system is made with ATP software and given in Fig. 8, arc is not considered and it is not modeled in ATP simulation. The system source was modeled with short-circuit current and the highest rms value of the symmetrical component of the polyphase short-circuit (short circuit from source side on bus 400 $\mathrm{kW}$, is $\mathrm{Ik} 3=20 \mathrm{kA}, \mathrm{Ik} 1=21 \mathrm{kA}$ ). The generator is modeled with dynamic parameters. The results of simulations are shown in Figs. $8 \div 13$.

The scheme of simulation is presented in Fig. 9.

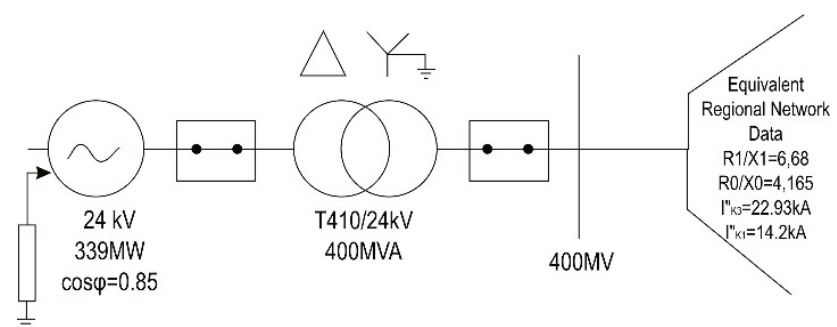

Figure 7 Real scheme of the generator in which fault happened and which is used for simulations

Figs. $8 \div 13$, present the simulation results with ATP software. The simulation is performed for asynchronous connection of generator to the network for different displacement angles between generator and power system. Simulations are performed for different angles between network and generation including an angle of $114^{\circ}$ degree. Angle $114^{\circ}$ is the angle where the incident occurred while the two other angles $\left(60^{\circ}, 80^{\circ}, 100^{\circ}\right.$ and $0^{\circ}$ ), are taken as arbitrary angles only for the purpose of analyses.

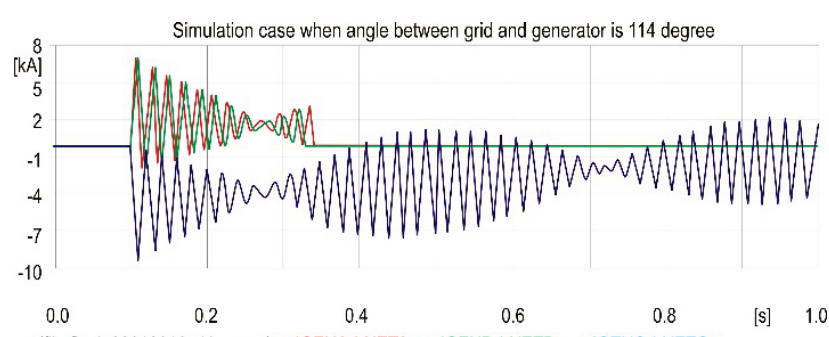

(file final_22012016.pl4: $x$-vart) c:IGENA-I-NETA c:IGENB-I-NETB c:IGENC-I-NETC

Figure 8 Simulation of Synchronization of generator into power system on wide angle $114^{\circ}$

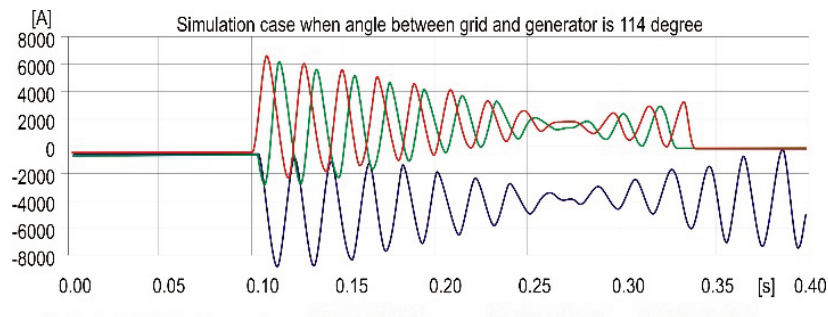

(file final_22012016.p14: $x$-vart) c:IGENA-I-NETA c:IGENB-I-NETB c:IGENC-INETC

Figure 9 Simulation of synchronization of generator into power system on wide angle $114^{\circ}$

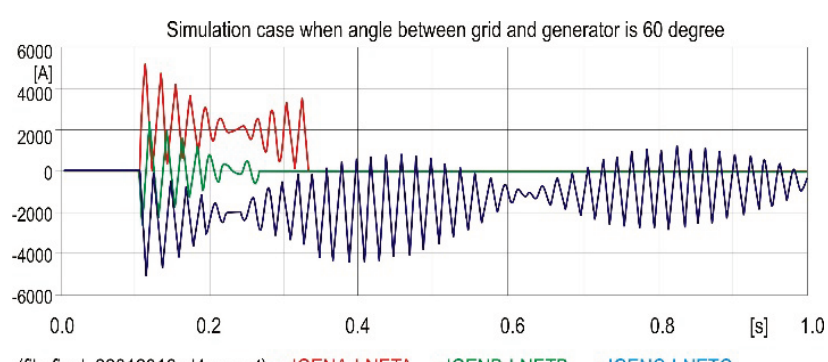

(file final_22012016.pl4: $x$-vart) c:IGENA-I-NETA c:IGENB-I-NETB c:IGENC-I-NETC

Figure 10 Simulation of synchronization of generator into power system on wide angle $60^{\circ}$

Through these simulations it can be seen that depending on the angle in which generator is connected to the network current varies on the particular phases as well as value of DC component. This has impact on the time delay of the AC component crossing through zero.

Similar simulations have been made even in the case of short circuit in order to compare the magnitude of DC 
component during the short circuit and asynchronous connection of the generator to the network.

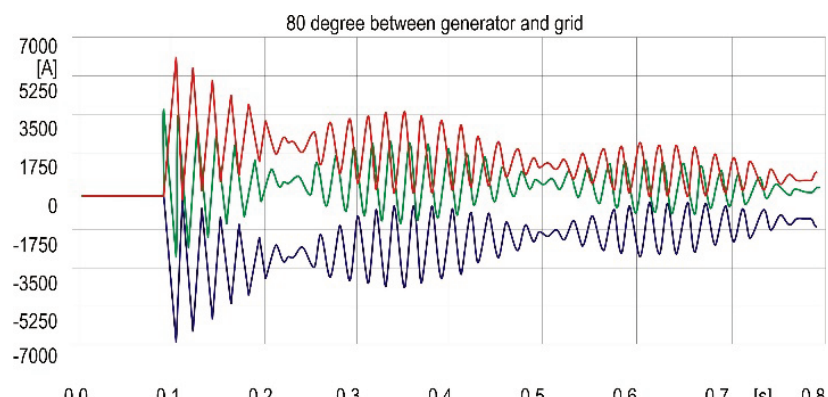
(file final 22012016.pl4: x-vart) c:IGENA-I-NETA c:IGENB-I-NETB c:IGENC-I-NETC

Figure 11 Simulation of synchronization of generator into power system on wide angle $80^{\circ}$

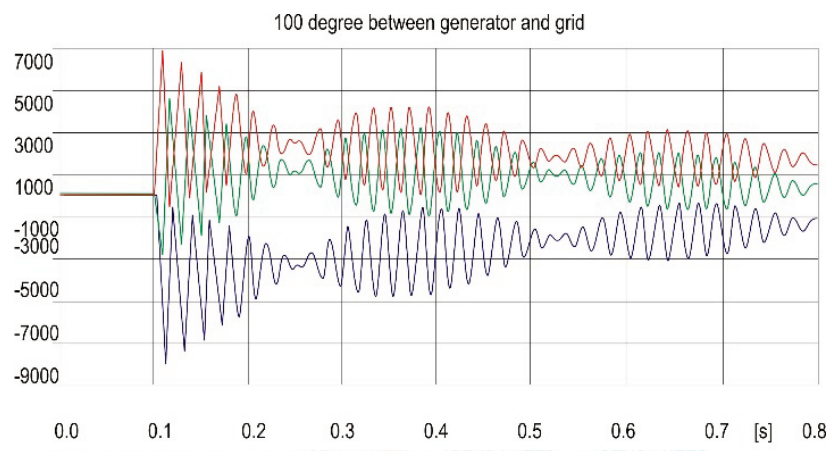
(file final_22012016.p14: $x$-vart) c:IGENA-I-NETA c:IGENB-I-NETB c:IGENC-I-NETC

Figure 12 Simulation of synchronization of generator into power system on wide angle $100^{\circ}$

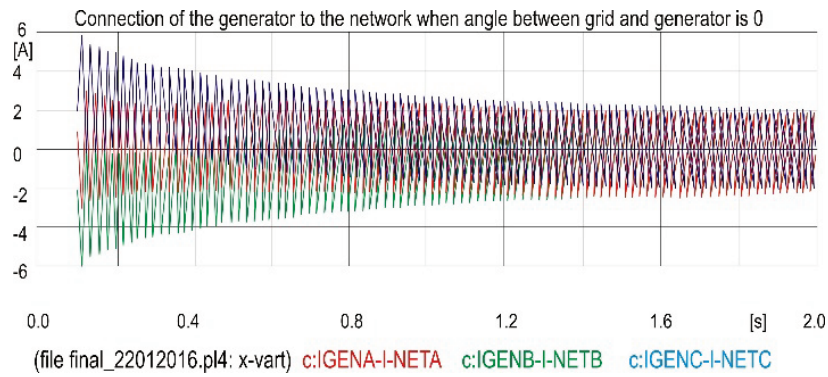

Figure 13 Simulation of Synchronization of generator into power system on wide angle $0^{\circ}$

Table 5 Value of DC component of current during short circuit

\begin{tabular}{|c|c|c|c|c|c|c|}
\hline \multirow[t]{3}{*}{ 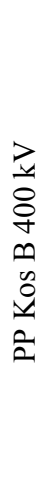 } & \multicolumn{4}{|c|}{$\begin{array}{l}\text { Value of DC component of current } \\
\text { during short circuit }\end{array}$} & \multicolumn{2}{|c|}{$\begin{array}{c}\text { Value of dc } \\
\text { component of } \\
\text { current during } \\
\text { asynchronous } \\
\text { connection of } \\
\text { generator to } \\
\text { network } \\
\text { without } \\
\text { meeting the } \\
\text { synchronizing } \\
\text { condition. }\end{array}$} \\
\hline & S (MVA) & $\begin{array}{c}I \\
(\mathrm{~A})\end{array}$ & $\begin{array}{l}I_{\mathrm{dyn}} \\
(\mathrm{A})\end{array}$ & $\begin{array}{l}I_{\mathrm{DC}} \\
(\mathrm{A})\end{array}$ & $\begin{array}{l}I_{\mathrm{AC}} \\
(\mathrm{A})\end{array}$ & $\begin{array}{l}I_{\mathrm{DC}} \\
(\mathrm{A})\end{array}$ \\
\hline & 15858.4 & 22890 & 59618.9 & 7274.5 & 2130 & 3600 \\
\hline
\end{tabular}

An analysis of short circuit near the generator is performed also using PSS/E software and ATP for transient analyses (We have used PSS/E for calculation of short circuit in the network since the model of the system of Kosovo and wider in the region is in PSS/E. In order to simulate the behavior of system during the fault the equivalent system was calculated with PSS/E. With ATP simulation tools is performed the modeling of only faulted generator during asynchronous connection, unit transformer and circuit breaker connected to equivalent network). Short circuit is simulated on bus bar $400 \mathrm{kV}$ when generator is connected. The results of short circuit current, maximum current (first peak of fault current) and DC component values are presented in Tab. 5.

During faults as result of short circuits, the initial value of DC component is higher than in case of asynchronous closing of the circuit breaker. However, DC component decreases very quickly and this allows for $\mathrm{AC}$ component to cross through zero, but in case of the asynchronous connection the time delay of DC component is much higher which in turn causes the effect on the $\mathrm{AC}$ component crossing time through zero making it thus higher $[16,17,18]$.

\section{Analyses and Discussion}

Circuit-breakers used for generator switching applications are subject to conditions quite different from those of normal circuit-breakers used in utility systems.

Usually in generator AC breaker during the disconnection process, serious problem occurs due to the presence of high value DC component that makes the AC component be delayed passing through zero. It is essential for AC current to pass through zero, namely the arc is extinguished in this point and its restart is more difficult, enabling a successful disconnection. In the abovementioned case, the value of the DC component reached the value of $3.11 \mathrm{kA}$, whereas the time delay of passing of the AC component through zero was $100 \mathrm{~ms}$. This is very long time for AC circuit breakers that perform the disconnection in less than $50 \mathrm{~ms}$.

Based on the results of performed simulations it can be concluded that the circuit breaker of generator shall be specified to be capable to disconnect the asymmetrical currents caused by short circuit where the DC exceeds the value of $7.3 \mathrm{kA}$. It is very important to consider also the time delay needed for the DC component to decrease enough in order that overall short circuit current passes through zero. This shall be specified carefully in the new circuit breakers and relay time settings.

\section{Conclusion}

This paper presents analysis of the performance of circuit breaker during disconnection of the failure currents that appear as a result of asynchronous connection of the generator on the grid. The analysis is based on the case of accidental closing of the circuit breaker without synchronization of generator to the network, because of failure on the control circuits of generator circuit breaker. The case is modeled using ATP and PSS/E software and results are compared with values recorded in real time of the voltages and currents.

The case which is analyzed in the paper was connection of the generator to the network by accident under the angle of $114^{\circ}$. In these circumstances the maximum value of asymmetric current is $130 \%$ of the peak value of symmetric in this case. Consequently, AC component of the current has not passed through zero for 
time $100 \mathrm{~ms}$. This caused the damage of the SF6 circuit breaker as the circuit breaker was not able to disconnect currents which did not pass through zero.

In the incident reported here, delaying the relay trip order to the high voltage circuit breaker for $70 \mathrm{~ms}$ would have been beneficial, allowing the DC component of current to enable current crossing through zero and so sufficient interruption without causing any damage to the circuit breaker.

Following conclusions can be made:

- Specification of generator circuit breakers requires special analyses of transient network processes respectively at connection point.

- The DC component specifically must be analyzed in detail, in order to specify the adequate circuit breaker that is capable to disconnect the current at different faults near the generator.

- Very often the transient disconnections with SF6 and ultra-fast relays are not advantageous for generator circuit breakers. In this case the disconnection delay is in favor of a successful disconnection with $\mathrm{AC}$ circuit breaker

- It is important to study the network for dimensioning of generator breakers for each case particularly.

- Very important to consider is also the time constant needed for the DC component to decrease enough in order that overall short circuit current passes through zero.

- Fast tripping relay protection at generator circuit breakers is not advantage in all practical circumstances.

- If the circuit breaker is installed near power plant, the time constant shall be taken greater hence a circuit breaker will be chosen with higher percentage value of DC component of short circuit current or with higher interrupting capability.

\section{References}

[1] Kundur, P. Power System Stability and Control, McGrawHill, inc. edition 1994, pp. 45-198, pp. 463-577.

[2] Machowski, J.; Bialek, J. W.; Bumby, J. R. Power System Dynamics and Stability, Jon Wiley \& Sons Ltd, second edition 2008, pp. 127-261.

[3] Garzon, R. D. High Voltage Circuit Breakers, Design and Applications, CRC Press, 2nd edition, 1996, pp 27-40, pp 381-410.

[4] IEC 62271-100 High-voltage alternating - current circuitbreakers, CEI/IEC 62271-100:2001+A1:2002

[5] International standard IEC 62271-100, High-voltage alternating-current circuit-breakers, 2003.

[6] International standard IEC 62271-203, Use and handling of sulphur hexafluoride (SF6) in high-voltage switchgear and controlgear, 2008.

[7] Kapetanovic, M. High Voltage Circuit Breakers, Sarajevo, 2011, pp. 235-265, pp. 347-413.

[8] Kapetanovic, M. Visokonaponski prekidaci, Eletrotehnicki fakultet, Sarajevo, BiH, 2002, pp. 170-180.

[9] Siemens launches world's first $1200 \mathrm{kV}$ SF6 Circuit Breaker. Retrieved 14 November 2011.

[10] Application guide: Live Tank Circuit Breakers, ABB High Voltage, 2010.

[11] Ježek, V. Short Circuit Capability of Generator Circuit Breaker, May 2011, Železná Ruda-Špičák, University of
West Bohemia, Czech Republic, Intensive Programme "Renewable Energy Sources", pp. 155-158, May 2011.

[12] Asymmetry characteristics of progressive short circuit on large synchronous generator is done by R. E. Owen, W. A. Lewis, EHV Conference, Los Angeles, July 12-17. 1970.

[13] Working Group, B5.04 International Guide on the Protection of Synchronous Generators, October 2011.

[14] Uglješić, I.; Filipović-Grčić, B.; Bojić, S. Analiza kvara $400 \mathrm{kV}$ SF6 prekidača uslijed isklopa dalekovoda u praznom hodu, HRO CIGRE, Cavtat 2013.

[15] "Applications of Disconnecting Circuit Breakers, Michael Faxå, p. 1". Retrieved 9 July 2012.

[16] TPP Kosovo B, SS 400/220 kV, report and recordings from damages of the circuit breaker, 2011.

[17] KOSTT, Electrical Equipment Code, $2^{\text {nd }}$ Edition, 2009, www.kostt.com

[18] KOSTT, Grid Code, 2008， $2^{\text {nd }}$ Edition, 2010, www.kostt.com

\section{Authors' addresses}

Avni Alidemaj, Eng., Mr. Sc

Kosovo Electricity Distribution and Supply,

KEDS, Bill Clinton Boulevard, no. 3

10000 Prishtina, Kosovo

Faculty of Electrical and Computer Engineering,

University of Prishtina, Bregu i Diellit, p.n.

10000 Prishtina, Kosovo

avalidemaj@gmail.com

Sreten Škuletić, Prof. Dr.

Faculty of Electrical Engineering,

University of Montenegro,

Džordža Vašingtona bb, 81000 Podgorica, Montenegro

skuletic@ac.me

Vladan Radulović, Doc. Dr.

Faculty of Electrical Engineering

University of Montenegro,

Džordža Vašingtona bb, 81000 Podgorica, Montenegro

vladanra@ac.me 